\title{
Inflation and Fiscal Deficits in Sub-Saharan Africa
}

\author{
Michael Bleaney $^{a}$ and Manuela Francisco ${ }^{b}$ \\ ${ }^{\text {a }}$ University of Nottingham \\ ${ }^{\mathrm{b}}$ World Bank
}

\begin{abstract}
Inflationary performance in sub-Saharan Africa since 1996 is examined. Median inflation has tended to be higher than in other regions of the developing world, such as MENA and Latin America. Inflation is highly persistent and is higher in countries that are less politically stable, in those without hard-peg exchange rate regimes, and in those with larger fiscal deficits. Inflation has declined over time, at least at the upper end of the distribution. There is no evidence that commitment devices such as inflation targeting have reduced inflation, but in SSA the sample is confined to two countries. Inflation typically spikes after a devaluation, and is sensitive to supply-side shocks. Movements in the real price of oil and rice (but not maize) have significantly affected the inflation rate. In countries that are poor in oil and minerals and therefore more reliant on agriculture, output growth is negatively correlated with inflation, presumably because, when the harvest is good and agricultural output is high, the extra supply reduces food prices. Fiscal balances also display considerable persistence and are more favourable in resource-rich and politically stable countries and in those with hard-peg exchange rate regimes, and have improved over time.
\end{abstract}

Keywords: fiscal balance, inflation, price shocks

JEL Classifications: E31, E32, H62

Disclaimer: The findings, interpretations, and conclusions expressed in this paper are entirely those of the authors. They do not necessarily represent the views of the World Bank Group, or those of the Executive Directors of the World Bank or the governments they represent. 


\section{Introduction}

The disinflation that was achieved in the advanced countries in the mid-1980s was slower to reach the developing world and emerging markets. Median consumer price inflation amongst the advanced countries fell from $9.2 \%$ p.a. in $1975-84$ to $3.6 \%$ in $1985-94,2.0 \%$ in $1995-$ 2004 and $2.3 \%$ in 2004-13. In middle-income and lower-income countries, the median inflation rate was $11.5 \%$ in $1975-84,10.5 \%$ in $1985-94,6.2 \%$ in $1995-2004$ and $5.6 \%$ in 2004-13. Inflation was thus effectively dead in the advanced countries from the mid-1980s, aided by the collapse in oil prices in 1986. In the developing world it was very much alive until at least the mid-1990s, since when there has been a gradual improvement.

The purpose of the present paper is to provide an overview of the interconnected issues of inflation, monetary growth and fiscal deficits in Sub-Saharan Africa (SSA) over the past two decades. Empirical work such as that of Catão and Terrones (2005) and Lin and Chu (2013) shows that fiscal deficits are likely to be inflationary only in lower-income countries where the constraints on government borrowing are most acute. At least until recent debt relief initiatives, most of sub-Saharan Africa has not been deemed sufficiently credit-worthy to borrow on international markets, whilst domestic debt markets also remain severely underdeveloped, which implies that the potential for fiscal deficits to be inflationary is particularly strong in SSA (Gueye and Sy, 2015).

Although the theoretical relationship between these variables is well understood, we are not aware of any recent analysis of SSA experience of the type that we present here. A particular issue is the role of supply-side shocks, which are likely to be important in SSA because of the large weight of agriculture in GDP and in the consumption basket. Various studies have demonstrated the sensitivity of SSA agricultural output to climatic factors (Abidoye and Odusola, 2015; Barrios et al., 2010; Block, 2014).

The paper is structured as follows. A broad picture of trends in inflation, monetary growth and fiscal balances is presented in Section One. The results of some regression analysis using panel data are presented in Section Two. Section Three considers the impact of shocks of various kinds: shocks to agricultural output, to oil prices and to the world price of staple foods that form a large part of the consumption basket in Africa. Section Four contains a brief discussion of fiscal balances. Conclusions are presented in Section Five. The data source is World Bank World Development Indicators except where stated otherwise. 


\section{Overview of trends}

Any statistical analysis of inflation has to confront the fact that the distribution is typically heavily skewed to the right: inflation can reach astronomical positive values but not large negative ones. In our regression analysis we deal with this in various ways that are discussed in the next section. At a more elementary statistical level, this implies that the median is a more appropriate measure of central tendency than the mean, whilst measures of spread such as the standard deviation are highly sensitive to outliers. Figure 1 shows the median inflation rate across SSA countries by year, and compares it with the same statistic for the Middle East and North Africa (MENA) and Latin American regions. In all regions there has been something of a downward trend, with median inflation rates after 1996 being somewhat lower than in the two decades up to that date; but in SSA inflation has tended to be a bit faster than in the other two regions in recent years, despite Latin America's inflationary reputation (inflation rates were particularly high in 1994 and 1995 in SSA because of the number of countries affected by the large devaluation of the CFA franc in January 1994). 
Fig. 1: Median Consumer Price Inflation (\% p.a.) in Different Regions

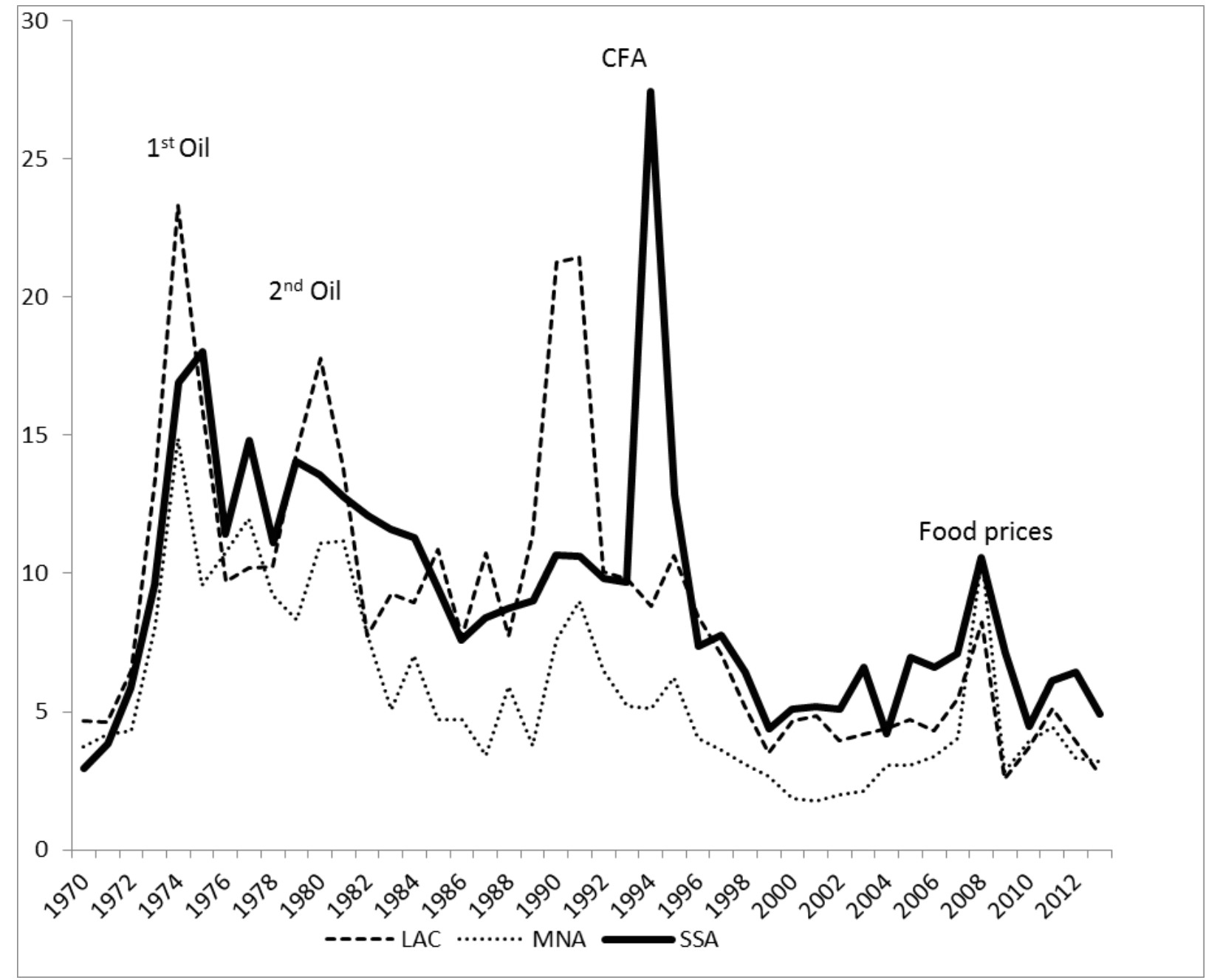

It is also useful to consider the proportion of countries with inflation above some threshold level. Exactly where the boundary lies between countries with major inflationary problems and those without is of course a matter of debate. Here we focus on two thresholds. The first is an inflation rate of $20 \%$, above which countries would appear to have significant inflationary problems that threaten to get out of control; and the second is an inflation rate of $10 \%$, above which we regard countries as having moderate inflationary problems. Below a $10 \%$ annual rate, it is not clear that inflation should be regarded as a major issue.

Figure 2 shows the proportion of SSA countries with inflation above each of these thresholds in each year. Particularly in the case of the higher threshold, the data suggest a distinct downward trend since the late 1990s, and in the case of both thresholds the picture today is much better than at any time in the period 1975-95. 
Fig. 2: Proportion of Countries in sub-Saharan Africa with Inflation above a Threshold Level

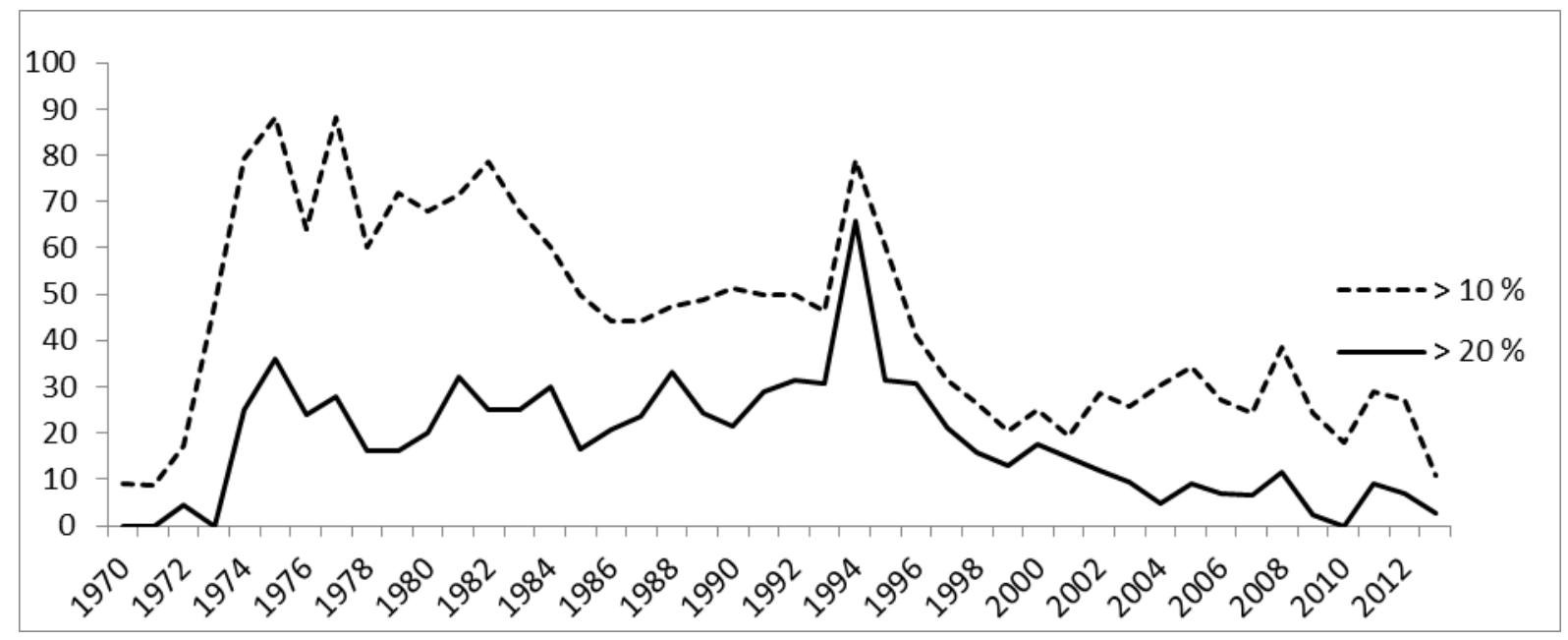

Fig 3: Median Fiscal Deficit (\% GDP) and Inflation in SSA 1980-2013

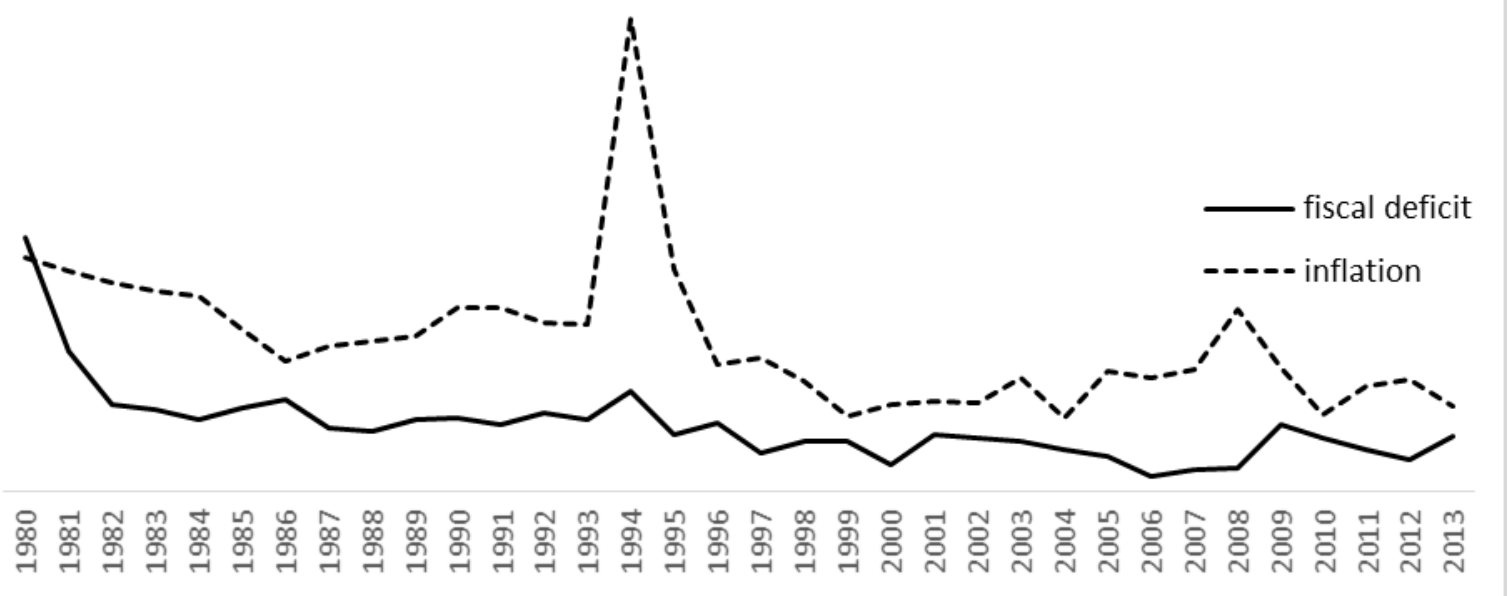


Fig 4: Median Fiscal Balance (\% GDP) in Different Regions

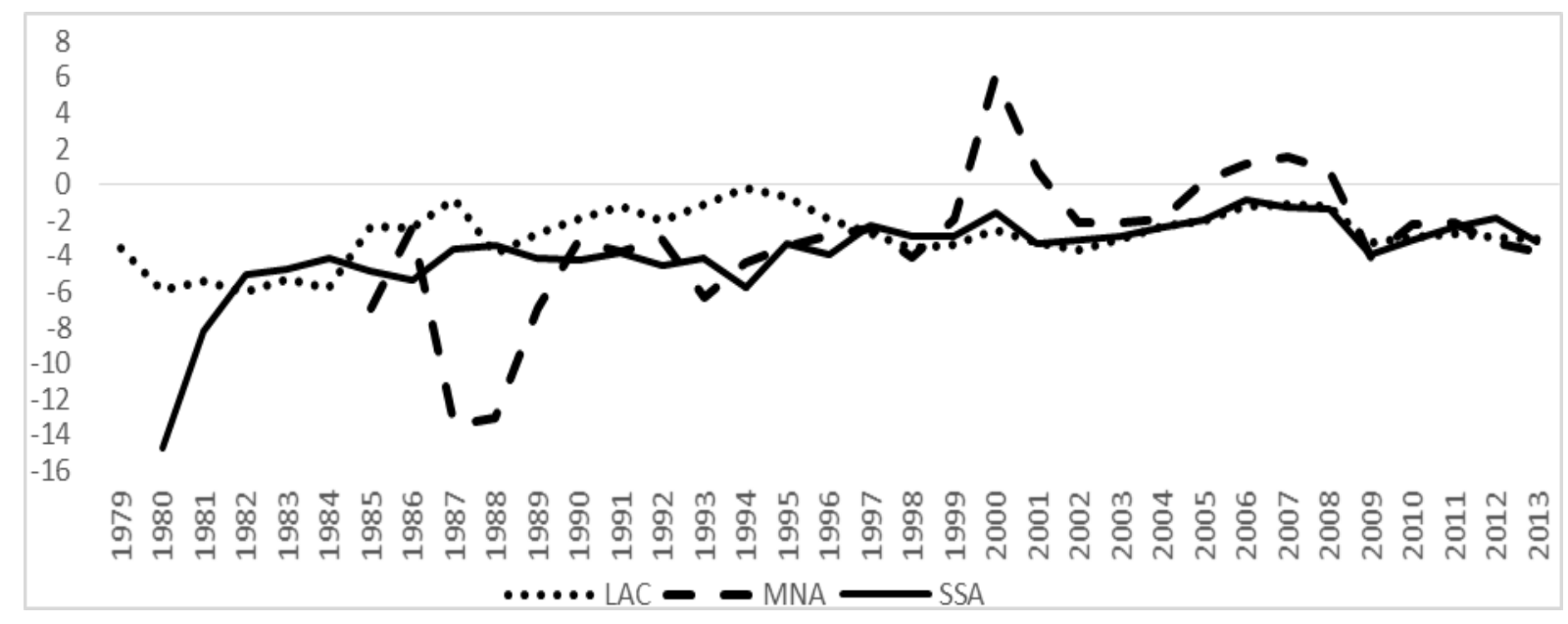

Fig 5: Percentage of SSA Countries with Fiscal Deficits above a Threshold Level (\% of GDP)

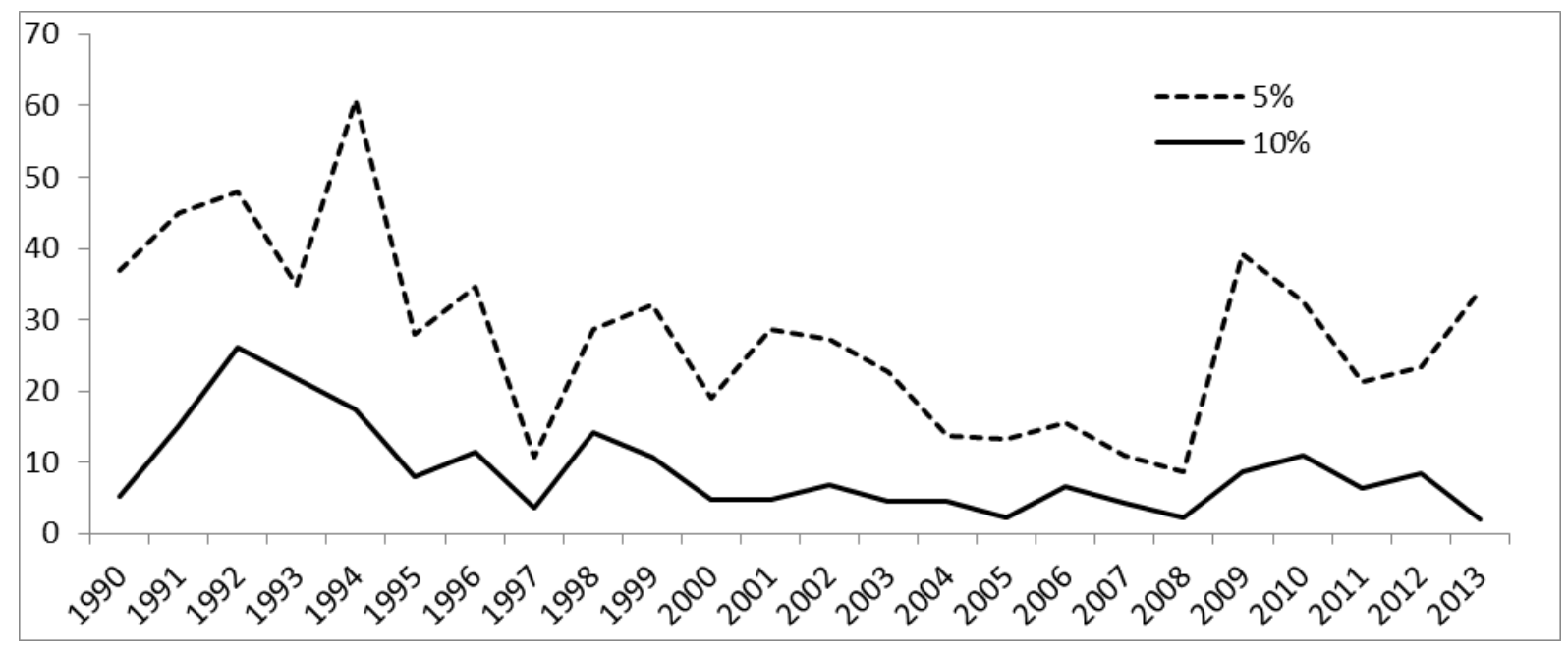

Table 1 shows the effect of fitting a regression line to the annual inflation data shown in Fig. 1. Transformed inflation has fallen on average by slightly less than a quarter of a percentage point per annum, and the trend is significant at $1 \%$. The probability of inflation exceeding $20 \%$ has also fallen by an estimated $1.1 \%$ per annum. This negative trend at the higher end of the scale is not matched when we consider a lower threshold. The probability of inflation exceeding $10 \%$ has also been falling gently, but the trend is not statistically significant. 
Table 1. Inflation in SSA 1996-2013

\begin{tabular}{|c|c|c|c|}
\hline & $\begin{array}{c}\text { Transformed } \\
\text { inflation }\end{array}$ & $\begin{array}{c}\text { Probit (inflation }> \\
20 \%)\end{array}$ & $\begin{array}{c}\text { Probit (inflation }> \\
10 \%)\end{array}$ \\
\hline Constant & $9.41 * * *$ & & \\
& $(13.7)$ & & -0.0032 \\
\hline Time & $-0.277 * * *$ & $-0.0112 * * *$ & $(-0.96)$ \\
& $(-3.45)$ & $(-5.01)$ & 691 \\
\hline $\mathrm{n}$ & 691 & 691 & 0.001 \\
\hline R-squared & 0.018 & 0.056 & \\
\hline Standard error & 10.49 & & \\
\hline
\end{tabular}

Notes. Figures in parentheses are robust t-statistics. *, **, ***: significant at 10,5 and $1 \%$ respectively. Transformed inflation $=100 \mathrm{p} /(1+\mathrm{p})$, where $\mathrm{p}$ is the change in the $\log$ of consumer prices. The probit regressions show the marginal effects and the pseudo-R-squared. Time = year minus 2000. 


\section{Inflation, money growth and fiscal deficits}

The relationship between fiscal deficits and inflation is clear in theory: persistent deficits are financed either by seigniorage revenue or by a build-up of debt that must be eventually either monetized or reversed by a strong fiscal correction (or debt reduction through either repudiation or forgiveness). The advanced countries have been helped in reducing their large post-World-War-Two debts by persistent, if mainly low, inflation, but the inflationary problems of the 1970s had no obvious fiscal cause. Countries like Belgium and Ireland, which built up large debt-GDP ratios in the late twentieth century, have subsequently successfully reduced them through fiscal adjustment rather than seigniorage. Nevertheless recent research by Catão and Terrones (2005) and Liu and Chu (2013) has demonstrated a significant long-run relationship between fiscal deficits and inflation, using annual data back to 1960 for a large sample of countries. ${ }^{1}$

In order to address the issue over a shorter data period, we use a simpler approach than the autoregressive distributed lag method used by these authors. We ignore the possibility of a correlation between current inflation and future fiscal deficits, and simply regress current inflation on current and past deficits. Theoretically, it is perfectly possible for governments to collect seigniorage revenue today and use it to build up fiscal surpluses that can be used to fund deficits tomorrow. As studies of hyperinflation show, however, in practice this never happens; inflation tends to undermine the real value of receipts from other taxes, because of the specification of tax liabilities in nominal terms combined with lags in collection. By the time tax revenues are collected, their real value is lower, the faster the price rise since the liability was incurred. We therefore assume as a first approximation that inflation can only cause current, but not future deficits, but that deficits can cause both current and future inflation, because the inflationary effects can be postponed through borrowing.

Table 2 shows bivariate regressions of transformed inflation on (a) the current year's ratio of the fiscal balance to GDP; and (b) the average of the same ratio over two, three and four years up to the current year. We use the ratio to GDP, even though Catão and Terrones (2005) show the ratio to narrow money (M1) to be theoretically preferable, because the M1 data are unreliable for some countries and Liu and Chu (2013) find the ratio to GDP to be a satisfactory alternative. In each case the coefficient is significant and negative, as expected.

\footnotetext{
${ }^{1}$ See Catão and Terrones (2005) for a theoretical model.
} 
The fit of the regression tends to improve as the period over which the fiscal balance is averaged is lengthened, with the $t$-statistic increasing in absolute value from -2.16 for the current year to -3.62 for the four-year average. This is consistent with the idea that persistent deficits are more likely to be inflationary. Nevertheless the proportion of the variation in inflation that is explained is very small, ranging from $0.4 \%$ for the current year to $1.5 \%$ for the four-year average. The magnitude of the coefficients implies that an increase in the fiscal deficit by one per cent of GDP is associated with higher inflation of 0.1 to 0.2 percentage points.

Table 2. Inflation and cumulated fiscal balances

\begin{tabular}{|c|c|c|c|c|}
\hline & $\begin{array}{l}\text { Transformed } \\
\text { inflation }\end{array}$ & $\begin{array}{l}\text { Transformed } \\
\text { inflation }\end{array}$ & $\begin{array}{l}\text { Transformed } \\
\text { inflation }\end{array}$ & $\begin{array}{l}\text { Transformed } \\
\text { inflation }\end{array}$ \\
\hline Constant & $\begin{array}{c}7.22 * * * \\
(20.0) \\
\end{array}$ & $\begin{array}{l}6.84 * * * \\
(20.9) \\
\end{array}$ & $\begin{array}{c}6.58 * * * \\
(22.6)\end{array}$ & $\begin{array}{l}6.32 * * * \\
(23.6)\end{array}$ \\
\hline $\begin{array}{c}\text { Fiscal } \\
\text { balance/GDP } \\
\text { (current year) }\end{array}$ & $\begin{array}{c}-10.59 * * \\
(-2.16)\end{array}$ & & & \\
\hline $\begin{array}{c}\text { Fiscal } \\
\text { balance/GDP } \\
\text { (average current } \\
\text { \& previous year) }\end{array}$ & & $\begin{array}{c}-17.63^{* * * *} \\
(-3.15)\end{array}$ & & \\
\hline $\begin{array}{c}\text { Fiscal } \\
\text { balance/GDP } \\
\text { (average of last } \\
\text { three years) }\end{array}$ & & & $\begin{array}{c}-18.58^{* * *} \\
(-3.13)\end{array}$ & \\
\hline $\begin{array}{c}\text { Fiscal } \\
\text { balance/GDP } \\
\text { (average of last } \\
\text { four years) }\end{array}$ & & & & $\begin{array}{c}-21.21 * * * \\
(-3.62)\end{array}$ \\
\hline $\mathrm{n}$ & 617 & 599 & 580 & 560 \\
\hline R-squared & 0.004 & 0.009 & 0.010 & 0.015 \\
\hline Standard error & 9.33 & 8.58 & 7.88 & 7.09 \\
\hline
\end{tabular}

Notes. Figures in parentheses are robust t-statistics. ${ }^{*}, * *, * * *$ significant at 10,5 and $1 \%$ respectively. SSA 1996-2013 excluding small countries (population $<1.5$ million).

Table 3 shows similar regressions for the probability that inflation is greater than $20 \%$. This time the fiscal deficit for the current year is not quite significant at the $10 \%$ level, but the deficit averaged over two, three or four years is significant at $1 \%$. As in Table 2, the $t$ statistic is highest for the four-year average, and the marginal effect implies that an increase in the deficit by $1 \%$ of GDP adds about $1 \%$ to the probability of inflation exceeding the $20 \%$ threshold. 
Table 3 . The probability of inflation $>20 \%$ and cumulated fiscal balances

\begin{tabular}{|c|c|c|c|c|}
\hline $\begin{array}{c}\text { Estimation } \\
\text { method: probit }\end{array}$ & $\begin{array}{c}\text { Prob (inflation > } \\
20 \%)\end{array}$ & $\begin{array}{c}\text { Prob (inflation }> \\
20 \%)\end{array}$ & $\begin{array}{c}\text { Prob (inflation }> \\
20 \%)\end{array}$ & $\begin{array}{c}\text { Prob (inflation }> \\
20 \%)\end{array}$ \\
\hline $\begin{array}{c}\text { Fiscal } \\
\text { balance/GDP } \\
\text { (current year) }\end{array}$ & -0.364 & & & \\
\hline $\begin{array}{c}\text { Fiscal } \\
\text { balance/GDP } \\
\text { (average current } \\
\& \text { previous year) }\end{array}$ & $(-1.63)$ & & & \\
\hline $\begin{array}{c}\text { Fiscal } \\
\text { balance/GDP } \\
\text { (average of last } \\
\text { three years) }\end{array}$ & & $\begin{array}{c}-0.758^{* * *} \\
(-3.01)\end{array}$ & \\
\hline $\begin{array}{c}\text { Fiscal } \\
\text { balance/GDP } \\
\text { (average of last } \\
\text { four years) }\end{array}$ & & & $-0.956^{* * *}$ & \\
\hline $\mathrm{n}$ & & & $-3.94)$ & \\
\hline pseudo-R-squared & 0.008 & & & $-0.996^{* * *}$ \\
\hline
\end{tabular}

Notes. The coefficients shown are marginal effects. Figures in parentheses are robust t-statistics. ${ }^{*}, * *, * * *$ : significant at 10, 5 and 1\% respectively. SSA 1996-2013 excluding small countries (population < 1.5 million).

In Table 4 the same exercise is repeated for the probability that inflation exceeds $10 \%$. The $t$ statistics show the same pattern of greater significance when the fiscal deficit is averaged over a longer period, but they are mostly lower than in Table 3. Nevertheless the estimated marginal effect is slightly larger than for the higher threshold. 
Table 4 . The probability of inflation $>10 \%$ and cumulated fiscal balances

\begin{tabular}{|c|c|c|c|c|}
\hline $\begin{array}{c}\text { Estimation } \\
\text { method: probit }\end{array}$ & $\begin{array}{c}\text { Prob (inflation > } \\
10 \%)\end{array}$ & $\begin{array}{c}\text { Prob (inflation > } \\
10 \% \text { ) }\end{array}$ & $\begin{array}{c}\text { Prob (inflation > } \\
10 \%)\end{array}$ & $\begin{array}{c}\text { Prob (inflation > } \\
10 \% \text { ) }\end{array}$ \\
\hline $\begin{array}{c}\text { Fiscal } \\
\text { balance/GDP } \\
\text { (current year) }\end{array}$ & $\begin{array}{c}-0.646^{*} \\
(-1.82)\end{array}$ & & & \\
\hline $\begin{array}{c}\text { Fiscal } \\
\text { balance/GDP } \\
\text { (average current } \\
\text { \& previous year) }\end{array}$ & & $\begin{array}{c}-0.945^{* *} \\
(-2.27)\end{array}$ & & \\
\hline $\begin{array}{c}\text { Fiscal } \\
\text { balance/GDP } \\
\text { (average of last } \\
\text { three years) }\end{array}$ & & & $\begin{array}{l}-1.11 * * \\
(-2.39)\end{array}$ & \\
\hline $\begin{array}{c}\text { Fiscal } \\
\text { balance/GDP } \\
\text { (average of last } \\
\text { four years) }\end{array}$ & & & & $\begin{array}{c}-1.38 * * * \\
(-2.82)\end{array}$ \\
\hline $\mathrm{n}$ & 617 & 599 & 580 & 560 \\
\hline pseudo-R-squared & 0.005 & 0.008 & 0.009 & 0.013 \\
\hline
\end{tabular}

Notes. The coefficients shown are marginal effects. Figures in parentheses are robust t-statistics. ${ }^{*}, * *, * * *$ : significant at 10, 5 and 1\% respectively. SSA 1996-2013 excluding small countries (population < 1.5 million).

In the rest of this section, we explore the determinants of inflation in sub-Saharan Africa more deeply. One of the purposes is to understand what underlies the improving trend. Is it because of better fiscal positions, greater political stability, or more widespread use of commitment devices such as inflation targeting or hard-peg exchange rate regimes? We shall find that, once inflation persistence is accounted for, the estimated time trend is no longer statistically significant and slightly positive, which suggests that the variables in our model help to explain the improvement in inflation performance since 1996.

The variables in our model, apart from the ratio of the fiscal balance to GDP, are: a measure of the exchange rate regime that distinguishes hard pegs (essentially the CFA zone in this context), other pegs and floats; the change in the logarithm of the real effective exchange rate (plus its lag), to capture imported inflation; an oil producer dummy for countries whose oil rents exceed $10 \%$ of GDP; a mineral producer dummy for countries whose natural resource rents other than oil exceed $10 \%$ of GDP; a measure of political stability; and a dummy for an inflation targeting regime. The source of the data is the World Bank's World Development Indicators database.

The omitted category of regime is a soft peg. With the exchange rate regime, as with a 
number of other variables, there is always the question of endogeneity: the regime might be chosen because of the inflation rate, rather than vice versa. In previous work we have argued that hard-peg regimes (currency unions or currency boards, each of which make unilateral decisions to devalue very difficult) can be regarded as exogenous (Bleaney and Francisco, 2005). This seems uncontroversial for sub-Saharan Africa, where hard pegs are primarily associated with being a former French colony. On the other hand, the decision between a float and a conventional peg is more likely to be endogenous to inflation. Floats are generally considered more volatile than pegs, but at higher inflation rates the real exchange rate becomes volatile also under pegs with periodic devaluations, which makes floating more tempting. The inclusion of a float dummy in the regression is intended to capture correlation rather than causation; even were it to emerge with a significant positive coefficient, we would not want to push the argument that floats cause inflation.

Similarly, we would not want to suggest that specialization in natural resources is theoretically associated with a higher (or a lower) inflation rate; but inclusion of dummy variables for these characteristics helps to test the robustness of the other coefficients.

The measure of political stability is the political risk rating supplied by International Country Risk Guide (ICRG), which is measured on a scale of zero (most risky) to 100 (least risky). This is one component of the widely used ICRG institutional quality index that also takes economic and financial risk into account. We omit the economic and financial risk components because they could be argued to be endogenous to inflation.

The political risk rating is based on twelve risk indicators, as judged by ICRG staff. Government stability, socioeconomic tensions, risks to investments, internal conflict and external conflict each count for a maximum of twelve points. Less important are: corruption, involvement of the military in politics, religious tensions, law and order, ethnic tensions, democratic accountability (all six points maximum) and the quality of the bureaucracy (four points maximum). The dummy for inflation targeting is equal to one only for Ghana (2002 onwards) and South Africa (2000 onwards).

Table 5 shows the results, once again for sub-Saharan African countries with population exceeding 1.5 million from 1996 onwards. The sample size is reduced because of the lack of political stability data for some countries. The first column shows the regression for 
transformed inflation. The R-squared of 0.379 is much higher than when only the fiscal balance was included as a regressor. The time trend now has a positive coefficient but it is not significant, which suggests that the improving inflation trend is associated with trends in the explanatory variables rather than omitted factors. The hard peg dummy has a highly significant negative coefficient, indicating that the CFA countries tend to have lower inflation. The float dummy has a positive but insignificant and small coefficient of about $0.6 \%$. Real exchange rate appreciation in the current year is surprisingly estimated to have a significant positive impact on inflation, which is almost exactly matched by the significant negative impact of lagged appreciation. The latter is more in line with the expected effect of imported inflation.

The fiscal balance has a negative coefficient that is significant at the $1 \%$ level. Its magnitude implies that a fiscal deficit that is larger by $1 \%$ of GDP is associated with approximately $0.3 \%$ p.a. of extra inflation, which is rather greater than implied by the bivariate regressions of Table 2. The production structure variables suggest that countries that specialize in non-oil mineral resources (about 15\% of the sample) have significantly higher inflation, while oil producers (also about $15 \%$ of the sample) may also do so (the coefficient is significant at only the $10 \%$ level). Political stability has a negative coefficient that is significant at the $1 \%$ level: countries with greater political risks tend to have higher inflation. The inflation targeting dummy has an insignificant but positive coefficient, which is the opposite of what was expected, but it is based on only two countries. 
Table 5. Additional variables

\begin{tabular}{|c|c|c|c|}
\hline $\begin{array}{c}\text { Dependent } \\
\text { variable: }\end{array}$ & $\begin{array}{c}\text { Transformed } \\
\text { inflation }\end{array}$ & $\begin{array}{c}\text { Probit (inflation > } \\
20 \%)\end{array}$ & $\begin{array}{c}\text { Probit (inflation }> \\
10 \%)\end{array}$ \\
\hline Constant & $15.02^{* * *}$ & & \\
& $(5.07)$ & & 0.0598 \\
Time & 0.024 & 0.0001 & $(1.11)$ \\
$(=0$ in 2000) & $(0.34)$ & $(0.08)$ & $-0.409^{* * *}$ \\
\hline Hard peg dummy & $-5.84^{* * *}$ & & $(-10.66)$ \\
\hline Float dummy & $(-8.50)$ & & 0.0003 \\
& 0.575 & $0.029^{*}$ & $(0.01)$ \\
\hline Change in ln & $(0.75)$ & $(1.89)$ & $0.566^{*}$ \\
(REER) & $(2.49)$ & 0.075 & $(1.86)$ \\
\hline Lagged change in & $-11.27^{* *}$ & $(0.87)$ & $-0.529^{*}$ \\
ln (REER) & $(-2.25)$ & -0.090 & $(-1.91)$ \\
\hline Fiscal & $-28.1^{* * *}$ & $-0.964^{* * *}$ & $-2.53^{* * *}$ \\
balance/GDP & $(-3.75)$ & $(-3.48)$ & $(-3.35)$ \\
\hline Non-oil mineral & $1.67^{* * *}$ & 0.0246 & $0.144^{*}$ \\
producer & $(2.45)$ & $(0.95)$ & $(1.87)$ \\
\hline Oil producer & $1.93^{*}$ & 0.626 & 0.159 \\
& $(1.72)$ & $(1.10)$ & $(1.64)$ \\
\hline Political stability & $-0.135^{* * *}$ & $-0.0025^{* * *}$ & $-0.0073^{* *}$ \\
& $(-3.05)$ & $(-2.65)$ & $(-2.35)$ \\
\hline Inflation targeting & 0.680 & 0.078 & 0.075 \\
dummy & $(0.64)$ & $(0.22)$ & $(0.68)$ \\
\hline $\mathrm{N}$ & 367 & 367 & 367 \\
\hline R-squared & 0.379 & 0.264 & 0.263 \\
\hline Standard error & 4.88 & & \\
\hline
\end{tabular}

Notes. Figures in parentheses are robust t-statistics. *,**,***: significant at 10,5 and $1 \%$ respectively. Transformed inflation $=100 \mathrm{p} /(1+\mathrm{p})$, where $\mathrm{p}$ is the change in the log of consumer prices. The probit regressions show the marginal effects and the pseudo-R-squared. The fiscal balance is the average of years T-3 to T. REER real effective exchange rate. Exchange rate regime data are from Bleaney and Tian (2014).

In short, the three variables that seemed a priori most likely to emerge significant and with the expected sign do so: the presence or absence of a hard peg, the fiscal balance and political stability.

The second and third columns of Table 5 are probits for inflation above $20 \%$ and $10 \%$ respectively, using the same regressors (except that the hard peg dummy is omitted for $20 \%$, because there are no cases of hard pegs with inflation that high). The point of estimating a probit is that an ordinary inflation regression may be unduly sensitive to a few outliers, and so replacing transformed inflation with the probability that inflation is above some threshold level can be seen as a form of robustness test. The figures of $20 \%$ and $10 \%$ are obviously arbitrary to some extent; inflation above $20 \%$ is relatively rare, representing only a few per 
cent of the sample, whereas about $20 \%$ of the observations exceed $10 \%$ inflation.

The three variables that are significant at $1 \%$ in column (1) remain significant with the same sign in the probits, but real exchange rate appreciation and resource specialization tend to lose significance. The marginal effects imply that a hard peg reduces the probability of inflation exceeding $10 \%$ by as much as 41 percentage points; being a non-oil mineral producer increases it by 27 percentage points; an improvement in the fiscal balance of $1 \%$ of GDP reduces it by 2.5 percentage points; and a one-standard-deviation improvement in political stability reduces it by 17 percentage points. Generally speaking, though, all three regressions in Table 5 present a similar picture.

Since political stability is quite highly correlated with per capita GDP, we can enlarge the sample quite a bit by substituting the latter for the former, and adding a simpler measure of political stability (a dummy for whether any battle deaths are recorded in that year, from internal or external conflict). The results are shown in Table 6. The sample size increases from 367 to 511. The R-squareds are somewhat lower, and the coefficients of the fiscal balance tend to be smaller in absolute value than in Table 5, although still statistically significant. The broad similarity between Tables 5 and 6 suggests that the regression is not very different in countries that have institutional quality data from those that have not (and we have confirmed this with a Chow test).

It is possible that the relationship between the inflation rate and the fiscal balance is nonlinear. To test this, we have tried adding the square of the fiscal balance to the regression, but it was never significant. We have also tried including world GDP growth, as a measure of global output shocks, but this variable was also not significant. 
Table 6. Replacing political instability by lagged real per capita GDP

\begin{tabular}{|c|c|c|c|}
\hline $\begin{array}{c}\text { Dependent } \\
\text { variable: }\end{array}$ & $\begin{array}{c}\text { Transformed } \\
\text { inflation }\end{array}$ & $\begin{array}{c}\text { Probit (inflation }> \\
20 \%)\end{array}$ & $\begin{array}{c}\text { Probit (inflation }> \\
10 \%)\end{array}$ \\
\hline Constant & $12.63^{* * *}$ & & \\
& $(7.99)$ & & $0.0071^{*}$ \\
Time & 0.067 & -0.0001 & $(1.72)$ \\
$(=0$ in 2000) & $(1.19)$ & $(-0.05)$ & $-0.339^{* * *}$ \\
\hline Hard peg dummy & $-5.49^{* * *}$ & & $(-10.37)$ \\
\hline Float dummy & $(-10.66)$ & & -0.005 \\
& 0.31 & $0.030^{*}$ & $(-0.12)$ \\
\hline Change in ln & $(0.50)$ & $(1.66)$ & 0.269 \\
(REER) & $(1.47$ & -0.013 & $(1.14)$ \\
\hline Lagged change in & $-9.88^{* *}$ & $(-0.13)$ & $-0.454^{* *}$ \\
ln (REER) & $(-2.25)$ & $-0.193^{* *}$ & $(-2.05)$ \\
\hline Fiscal & $-16.9^{* * *}$ & $-0.35)$ & $-1.51^{* *}$ \\
balance/GDP & $(-3.07)$ & $(-4.33)$ & $(-2.79)$ \\
\hline Non-oil mineral & $1.39^{* *}$ & 0.031 & $0.175^{* *}$ \\
producer & $(2.47)$ & $(1.02)$ & $(2.54)$ \\
\hline Oil producer & $3.05^{* * *}$ & $0.118^{* *}$ & $0.392^{* * *}$ \\
& $(3.08)$ & $(2.20)$ & $(5.07)$ \\
\hline Lagged ln(GDPpc & $-0.915^{* * *}$ & -0.0119 & $-0.0967^{* * *}$ \\
in constant US\$) & $(-4.20)$ & $(-1.36)$ & $(-5.11)$ \\
\hline Inflation targeting & 1.16 & -0.0068 & $0.232^{* * *}$ \\
dummy & $(1.32)$ & $(-0.19)$ & $(2.02)$ \\
\hline $\mathrm{n}$ & 511 & 511 & 511 \\
\hline R-squared & 0.304 & 0.144 & 0.258 \\
\hline Standard error & 5.01 & & \\
\hline
\end{tabular}

Notes. Figures in parentheses are robust t-statistics. *,**,***: significant at 10,5 and $1 \%$ respectively. ERR data: Bleaney \& Tian (2014). Transformed inflation $=100 \mathrm{p} /(1+\mathrm{p})$, where $\mathrm{p}$ is the change in the log of consumer prices. The probit regressions show the marginal effects and the pseudo-R-squared. The fiscal balance is the average of years T-3 to T. Exchange rate regime data are from Bleaney and Tian (2014).

In Tables 7 and 8 we add the lagged dependent variable to the model, to capture inflation persistence, first with political stability (Table 7) and then with per capita GDP (Table 8). The lagged dependent variable is always highly significant, and its inclusion greatly improves the fit. On the other hand all the other variables tend to get less significant than before. In Table 7 the hard peg dummy is still significant at the $1 \%$ level. The fiscal balance is still significant at $5 \%$ in all three cases, whereas it was significant at $1 \%$ in all three cases in Table 5. The time trend is still insignificant with a small positive sign. 
Table 7. With lagged inflation and political instability

\begin{tabular}{|c|c|c|c|}
\hline $\begin{array}{c}\text { Dependent } \\
\text { variable: }\end{array}$ & $\begin{array}{c}\text { Transformed } \\
\text { inflation }\end{array}$ & $\begin{array}{c}\text { Probit (inflation }> \\
20 \%)\end{array}$ & $\begin{array}{c}\text { Probit (inflation }> \\
10 \%)\end{array}$ \\
\hline Constant & $5.86^{* * *}$ & & \\
& $(2.67)$ & & $0.331^{* * *}$ \\
\hline Lagged dependent & $0.538^{* * *}$ & $0.353^{* *}$ & $(5.22)$ \\
variable & $(8.10)$ & $(2.43)$ & 0.0051 \\
\hline Time & $0.0965^{*}$ & 0.00159 & $(0.90)$ \\
(=0 in 2000) & $(1.74)$ & $(1.43)$ & $-0.340^{* * *}$ \\
\hline Hard peg dummy & $-2.60^{* * *}$ & & $(-7.09)$ \\
\hline Float dummy & $(-3.44)$ & & -0.0096 \\
& 0.23 & 0.0141 & $(-0.18)$ \\
\hline Change in ln & $(0.38)$ & $(1.22)$ & 0.322 \\
(REER) & 2.43 & -0.0167 & $(1.02)$ \\
\hline Lagged change in & $-16.623^{* * *}$ & $-0.0928^{*}$ & $-0.748 * *$ \\
ln (REER) & $(-4.47)$ & $(-1.80)$ & $(-2.39)$ \\
\hline Fiscal & $-10.71^{* *}$ & $-0.420^{* *}$ & $-2.76^{* *}$ \\
balance/GDP & $(-2.00)$ & $(-2.39)$ & $(-2.22)$ \\
\hline Non-oil mineral & 0.49 & -0.0095 & 0.091 \\
producer & $(0.89)$ & $(-0.91)$ & $(1.12)$ \\
\hline Oil producer & 0.95 & 0.0186 & 0.144 \\
& $(1.41)$ & $(0.78)$ & $(1.56)$ \\
\hline Political stability & $-0.053^{*}$ & -0.00149 & -0.00463 \\
& $(-1.79)$ & $(-1.35)$ & $(-1.34)$ \\
\hline Inflation targeting & -0.035 & 0.0009 & 0.0272 \\
dummy & $(-0.04)$ & $(0.01)$ & $(0.26)$ \\
\hline $\mathrm{n}$ & 363 & 363 & 363 \\
\hline R-squared & 0.609 & 0.441 & 0.335 \\
\hline Standard error & 3.87 & & \\
\hline
\end{tabular}

Notes. Figures in parentheses are robust t-statistics. *,**,***: significant at 10,5 and $1 \%$ respectively. Transformed inflation $=100 \mathrm{p} /(1+\mathrm{p})$, where $\mathrm{p}$ is the change in the log of consumer prices. The probit regressions show the marginal effects and the pseudo-R-squared. The fiscal balance is the average of years T-3 to T. Exchange rate regime data are from Bleaney and Tian (2014).

Table 8 includes the lagged dependent variable with per capita GDP rather than political stability. The hard peg dummy and the fiscal balance remain consistently significant. The estimated coefficients of the fiscal balance (and other variables) are smaller in absolute value in Tables 7 and 8, because they measure only the impact effect, and the estimated long-run effect is greater than the impact effect because of inflation persistence. If the estimated coefficient of the lagged dependent variable is $a$, the ratio of the estimated long-run effect of a variable to the estimated short-run effect is $1 /(1-a)$. Using this formula, the estimated longrun effect of the fiscal balance is fairly similar in Tables 7 and 8 to in Tables 5 and 6 respectively. 
Table 8. With lagged inflation and lagged real per capita GDP

\begin{tabular}{|c|c|c|c|}
\hline $\begin{array}{l}\text { Dependent } \\
\text { variable: }\end{array}$ & $\begin{array}{c}\text { Transformed } \\
\text { inflation }\end{array}$ & $\begin{array}{c}\text { Probit (inflation }> \\
20 \% \text { ) }\end{array}$ & $\begin{array}{c}\text { Probit (inflation }> \\
10 \% \text { ) }\end{array}$ \\
\hline Constant & $\begin{array}{l}6.15 * * * \\
(3.42)\end{array}$ & & \\
\hline $\begin{array}{l}\text { Lagged dependent } \\
\text { variable }\end{array}$ & $\begin{array}{l}0.460 * * * \\
(6.74)\end{array}$ & $\begin{array}{c}0.400 * * * \\
(3.81)\end{array}$ & $\begin{array}{c}0.237 * * * \\
(4.45)\end{array}$ \\
\hline $\begin{array}{c}\text { Time } \\
(=0 \text { in } 2000)\end{array}$ & $\begin{array}{l}0.105 * * \\
(2.30)\end{array}$ & $\begin{array}{l}0.00155 \\
(1.05)\end{array}$ & $\begin{array}{c}0.00611 \\
(1.44)\end{array}$ \\
\hline Hard peg dummy & $\begin{array}{c}-2.93 * * * \\
(-4.82)\end{array}$ & & $\begin{array}{c}-0.291 * * * \\
(-8.12)\end{array}$ \\
\hline Float dummy & $\begin{array}{l}0.048 \\
(0.09)\end{array}$ & $\begin{array}{r}0.0085 \\
(0.65)\end{array}$ & $\begin{array}{l}-0.0047 \\
(-0.12)\end{array}$ \\
\hline $\begin{array}{l}\text { Change in ln } \\
\text { (REER) }\end{array}$ & $\begin{array}{l}-0.141 \\
(-0.02)\end{array}$ & $\begin{array}{l}-0.101 * \\
(-1.63)\end{array}$ & $\begin{array}{l}0.080 \\
(0.33)\end{array}$ \\
\hline $\begin{array}{l}\text { Lagged change in } \\
\text { ln (REER) }\end{array}$ & $\begin{array}{c}-13.75 * * * \\
(-2.77)\end{array}$ & $\begin{array}{l}-0.131 * \\
(-1.89)\end{array}$ & $\begin{array}{c}-0.577 * * \\
(-2.11)\end{array}$ \\
\hline $\begin{array}{c}\text { Fiscal } \\
\text { balance/GDP }\end{array}$ & $\begin{array}{l}-8.47^{*} \\
(-1.87)\end{array}$ & $\begin{array}{c}-0.454 * * * \\
(-2.61)\end{array}$ & $\begin{array}{l}-1.13 * * \\
(-2.03)\end{array}$ \\
\hline $\begin{array}{l}\text { Non-oil mineral } \\
\text { producer }\end{array}$ & $\begin{array}{l}0.538 \\
(1.12)\end{array}$ & $\begin{array}{c}-0.0062 \\
(-0.38)\end{array}$ & $\begin{array}{c}0.332 * * * \\
(4.25)\end{array}$ \\
\hline Oil producer & $\begin{array}{l}1.74 * * \\
(2.34)\end{array}$ & $\begin{array}{l}0.0553^{*} \\
(1.72)\end{array}$ & $\begin{array}{l}0.127 * \\
(1.79)\end{array}$ \\
\hline $\begin{array}{l}\text { Lagged } \ln (\mathrm{GDPpc} \\
\text { in constant US } \$)\end{array}$ & $\begin{array}{c}-0.453 * * \\
(-2.09)\end{array}$ & $\begin{array}{l}-0.0091 \\
(-1.23)\end{array}$ & $\begin{array}{c}-0.0755 * * * \\
(-3.92)\end{array}$ \\
\hline $\begin{array}{l}\text { Inflation targeting } \\
\text { dummy }\end{array}$ & $\begin{array}{l}0.346 \\
(0.43)\end{array}$ & $\begin{array}{l}-0.0096 \\
(-0.36)\end{array}$ & $\begin{array}{l}0.161 \\
(1.43)\end{array}$ \\
\hline$n$ & 505 & 505 & 505 \\
\hline R-squared & 0.476 & 0.338 & 0.301 \\
\hline Standard error & 4.35 & & \\
\hline
\end{tabular}

Notes. Figures in parentheses are robust t-statistics. *, **, ***: significant at 10,5 and $1 \%$ respectively. Transformed inflation $=100 \mathrm{p} /(1+\mathrm{p})$, where $\mathrm{p}$ is the change in the $\log$ of consumer prices. The probit regressions show the marginal effects and the pseudo-R-squared. The fiscal balance is the average of years T-3 to T. Exchange rate regime data are from Bleaney and Tian (2014). 


\section{Supply-side shocks}

When agricultural production, including the production of food, represents a sizeable proportion of output, then fluctuations of real GDP about its trend are likely to be strongly influenced by environmental conditions that determine the quality of the harvest. For example Block (2014, Table 2) estimates that $10 \%$ more rainfall in sub-Saharan Africa increases crop output per agricultural worker by $3.7 \%$. Moreover in low-income economies food typically represents a large proportion of consumption. When conditions boost food production, GDP is higher but food prices are lower, and so is the consumer price index. In first differences, inflation will be negatively correlated with GDP growth. Since this effect is likely to be weaker in countries that produce a lot of oil or other minerals, and where agriculture is consequently less important, we allow the coefficient to differ between countries with large natural resource rents and those without. We also include a measure of the output gap to capture possible Phillips curve effects, even though previous research suggests that they are not significant in sub-Saharan Africa (Male, 2010). To allow for fluctuations in world commodity prices, we include changes in the world (real US\$) price of oil and basic foodstuffs (rice, maize) in the regression.

Table 9 shows the results for the smaller sample for which the political stability measure is available. The float dummy is omitted since it has never been significant in previous tables. Inclusion of the variables that are intended to capture supply-side shocks makes the hard-peg dummy, the fiscal balance and political stability even more significant than in Table 7 . The output gap is never significant and only has the expected positive sign in one case (the $10 \%$ probit). The supply-side variables tend not to be significant in the $20 \%$ probit, presumably because supply-side shocks are not usually large enough to propel countries over the $20 \%$ inflation threshold, but the world price of rice is highly significant in columns (1) and (3). World oil and maize prices have the expected positive coefficient but are less significant. Output growth for resource-rich economies has a positive coefficient and is never significant. Output growth in resource-poor economies is significant with the expected negative coefficient at $10 \%$ in column (1) and $5 \%$ in column (3). Taking the point estimates from the first column of Table 9 suggests that a $10 \%$ increase in the real price of oil, rice and maize add about $0.2,0.6$ and 0.1 percentage points respectively to the inflation rate, whilst a $1 \%$ reduction in the growth rate in resource-poor countries increases inflation by about $0.1 \%$. 
Table 10 shows the same regression for the larger sample using real per capita GDP instead of political stability. The coefficient of output growth for resource-poor economies is now significantly negative at the $1 \%$ level in columns (1) and ((3), and as predicted is more negative than the same coefficient for resource-rich economies. Rice prices are significantly positive at $1 \%$ in two out of three cases. As in Table 9, the maize price coefficient, although positive, is never significant.

Table 9. With price shocks and institutional quality

\begin{tabular}{|c|c|c|c|}
\hline $\begin{array}{c}\text { Dependent } \\
\text { variable: }\end{array}$ & $\begin{array}{c}\text { Transformed } \\
\text { inflation }\end{array}$ & $\begin{array}{c}\text { Probit (inflation }> \\
20 \%)\end{array}$ & $\begin{array}{c}\text { Probit (inflation } \\
10 \%)\end{array}$ \\
\hline Constant & $6.24 * * *$ & & \\
& $(3.61)$ & & $0.416^{* * *}$ \\
\hline Lagged dependent & $0.571^{* * *}$ & $0.415^{* * *}$ & $(5.72)$ \\
variable & $(8.92)$ & $(3.05)$ & -0.00116 \\
\hline Time & 0.0647 & 0.00047 & $(-0.19)$ \\
(=0 in 2000) & $(1.00)$ & $(0.78)$ & $-0.349^{* * *}$ \\
\hline Hard peg dummy & $-2.66^{* * *}$ & & $(-8.71)$ \\
\hline Change in ln & $(-5.38)$ & & -0.192 \\
(REER) & -1.76 & -0.0329 & $(-0.67)$ \\
\hline Lagged change in & $-16.50)$ & $(-0.88)$ & $-0.758^{* *}$ \\
ln (REER) & $(-4.89)$ & -0.0534 & $(-2.25)$ \\
\hline Fiscal & $-12.6^{* * *}$ & $(-1.43)$ & $-2.25^{* * *}$ \\
balance/GDP & $(-2.87)$ & -0.195 & $(-3.71)$ \\
\hline Political stability & $-0.0571^{* *}$ & $-0.00105^{* *}$ & $-0.00566^{* *}$ \\
& $(-2.25)$ & $(-2.07)$ & $(-2.17)$ \\
\hline dln (real oil price) & $1.95^{*}$ & $0.0353^{* *}$ & 0.130 \\
& $(1.93)$ & $(2.10)$ & $(0.96)$ \\
\hline Output gap & -0.96 & -0.053 & 0.230 \\
& $(-0.21)$ & $(-0.92)$ & $(0.52)$ \\
\hline NR dummy* & 3.35 & 0.030 & 0.668 \\
gdp growth & $(0.75)$ & $(0.53)$ & $(1.32)$ \\
\hline No NR dummy $*$ & $-13.88^{*}$ & 0.085 & $-1.730^{* *}$ \\
gdp growth & $(-1.80)$ & $(1.13)$ & $(-2.53)$ \\
\hline dln (real rice & $6.09 * * *$ & 0.769 & $0.734^{* * *}$ \\
price) & $(6.37)$ & $(0.86)$ & $(4.67)$ \\
\hline dln (real maize & 0.86 & $1.36^{*}$ & 0.120 \\
price) & $(0.59)$ & $(1.65)$ & $(0.80)$ \\
\hline N & 363 & 388 & 363 \\
\hline R-squared & 0.661 & 0.495 & 0.434 \\
\hline Standard error & 3.61 & & \\
\hline
\end{tabular}

Notes. Figures in parentheses are robust t-statistics. $*, * *, * * *$ : significant at 10,5 and $1 \%$ respectively. Transformed inflation $=100 \mathrm{p} /(1+\mathrm{p})$, where $\mathrm{p}$ is the change in the log of consumer prices. The probit regressions show the marginal effects and the pseudo-R-squared. The fiscal balance is the average of years T-3 to T. Output gap: deviation of $\ln ($ real GDP) from Hodrick-Prescott trend. Exchange rate regime data are from Bleaney and Tian (2014). 
Table 10. With price shocks and lagged real per capita GDP

\begin{tabular}{|c|c|c|c|}
\hline $\begin{array}{l}\text { Dependent } \\
\text { variable: }\end{array}$ & $\begin{array}{c}\text { Transformed } \\
\text { inflation }\end{array}$ & $\begin{array}{c}\text { Probit (inflation > } \\
20 \% \text { ) }\end{array}$ & $\begin{array}{c}\text { Probit (inflation > } \\
10 \% \text { ) }\end{array}$ \\
\hline Constant & $\begin{array}{c}6.74 * * * \\
(4.17)\end{array}$ & & \\
\hline $\begin{array}{l}\text { Lagged dependent } \\
\text { variable }\end{array}$ & $\begin{array}{l}0.503 * * * \\
(7.49)\end{array}$ & $\begin{array}{c}0.389 * * * \\
(3.97)\end{array}$ & $\begin{array}{c}0.329 * * * \\
(5.65)\end{array}$ \\
\hline $\begin{array}{c}\text { Time } \\
(=0 \text { in } 2000)\end{array}$ & $\begin{array}{l}0.0656 \\
(1.25)\end{array}$ & $\begin{array}{c}0.00028 \\
(0.31)\end{array}$ & $\begin{array}{c}0.00264 \\
(0.60)\end{array}$ \\
\hline Hard peg dummy & $\begin{array}{l}-2.82 * * * \\
(-6.04)\end{array}$ & $\begin{array}{l}-0.0127 \\
(-1.62)\end{array}$ & $\begin{array}{c}-0.284 * * * \\
(-9.11)\end{array}$ \\
\hline $\begin{array}{l}\text { Change in ln } \\
\text { (REER) }\end{array}$ & $\begin{array}{c}-3.40 \\
(-0.64)\end{array}$ & $\begin{array}{l}0.0217 \\
(0.90)\end{array}$ & $\begin{array}{l}-0.0899 \\
(-0.44)\end{array}$ \\
\hline $\begin{array}{l}\text { Lagged change in } \\
\text { ln (REER) }\end{array}$ & $\begin{array}{c}-13.76^{* * * *} \\
(-2.93)\end{array}$ & $\begin{array}{l}0.0437 \\
(1.32)\end{array}$ & $\begin{array}{c}-0.529 * * \\
(-1.96)\end{array}$ \\
\hline $\begin{array}{c}\text { Fiscal } \\
\text { balance/GDP }\end{array}$ & $\begin{array}{c}-10.7 * * * \\
(-2.78)\end{array}$ & $\begin{array}{l}-0.216^{*} \\
(-1.88)\end{array}$ & $\begin{array}{c}-1.38 * * * \\
(-3.19)\end{array}$ \\
\hline $\begin{array}{l}\text { Lagged } \ln (\mathrm{GDPpc} \\
\text { in constant US\$) }\end{array}$ & $\begin{array}{c}-0.461 * * \\
(-2.59)\end{array}$ & $\begin{array}{l}-0.0050 \\
(-1.32)\end{array}$ & $\begin{array}{c}-0.0678 * * * \\
(-4.03)\end{array}$ \\
\hline dln (real oil price) & $\begin{array}{c}1.50 \\
(1.55)\end{array}$ & $\begin{array}{c}0.0489 * * \\
(2.30)\end{array}$ & $\begin{array}{l}0.0578 \\
(0.57)\end{array}$ \\
\hline Output gap & $\begin{array}{c}1.47 \\
(0.37)\end{array}$ & $\begin{array}{l}-0.047 \\
(-0.74)\end{array}$ & $\begin{array}{l}0.050 \\
(0.14)\end{array}$ \\
\hline $\begin{array}{l}\text { NR dummy * } \\
\text { gdp growth }\end{array}$ & $\begin{array}{c}0.82 \\
(0.16)\end{array}$ & $\begin{array}{l}-0.016 \\
(-0.18)\end{array}$ & $\begin{array}{l}0.829 * \\
(1.69)\end{array}$ \\
\hline $\begin{array}{l}\text { No NR dummy } * \\
\text { gdp growth }\end{array}$ & $\begin{array}{c}-24.96 * * * \\
(-3.79) \\
\end{array}$ & $\begin{array}{l}-0.125 \\
(-1.56) \\
\end{array}$ & $\begin{array}{c}-1.93 * * * \\
(-3.45)\end{array}$ \\
\hline $\begin{array}{l}\mathrm{d} \ln \text { (real rice } \\
\text { price) }\end{array}$ & $\begin{array}{l}7.52 * * * \\
(7.03)\end{array}$ & $\begin{array}{l}0.0397 * \\
(1.92)\end{array}$ & $\begin{array}{c}0.665^{* * * *} \\
(6.27)\end{array}$ \\
\hline $\begin{array}{l}\text { dln (real maize } \\
\text { price) }\end{array}$ & $\begin{array}{l}0.063 \\
(0.05)\end{array}$ & $\begin{array}{l}0.0404 \\
(1.61)\end{array}$ & $\begin{array}{l}0.0002 \\
(0.00)\end{array}$ \\
\hline $\mathrm{n}$ & 505 & 538 & 505 \\
\hline R-squared & 0.547 & 0.423 & 0.386 \\
\hline Standard error & 4.05 & & \\
\hline
\end{tabular}

Notes. Figures in parentheses are robust t-statistics. *,**, ***: significant at 10, 5 and $1 \%$ respectively. Transformed inflation $=100 \mathrm{p} /(1+\mathrm{p})$, where $\mathrm{p}$ is the change in the log of consumer prices. The probit regressions show the marginal effects and the pseudo-R-squared. The fiscal balance is the average of years T-3 to T. Output gap: deviation of $\ln ($ real GDP) from Hodrick-Prescott trend. Exchange rate regime data are from Bleaney and Tian (2014). 
Do the results look very different if we introduce country fixed effects? One disadvantage is that some degree of bias is introduced into the OLS coefficients by having the lagged dependent variable as well, although the bias is limited by the relatively long time dimension of the panel (as the time dimension tends to infinity, the bias tends to zero). Table 11 shows the results (the probits are omitted because the algorithm failed to converge). Some variables with little time variation (e.g. political stability) have been omitted. The results are similar to Table 10.

Table 11. With country fixed/random effects

\begin{tabular}{|c|c|}
\hline $\begin{array}{c}\text { Dependent } \\
\text { variable: }\end{array}$ & $\begin{array}{c}\text { Transformed } \\
\text { inflation }\end{array}$ \\
\hline $\begin{array}{c}\text { Lagged dependent } \\
\text { variable }\end{array}$ & $\begin{array}{c}0.399 * * * \\
(4.45)\end{array}$ \\
\hline Time & 0.0408 \\
(=0 in 2000) & $(0.83)$ \\
\hline Change in ln & -3.26 \\
(REER) & $(-0.50)$ \\
\hline Lagged change in & $-14.78^{*} *$ \\
ln (REER) & $(-3.45)$ \\
\hline Fiscal & $-6.76 *$ \\
balance/GDP & $(-1.95)$ \\
\hline dln (real oil price) & 0.89 \\
& $(0.98)$ \\
\hline Output gap & -0.99 \\
& $(-0.26)$ \\
\hline NR dummy $*$ & -0.80 \\
gdp growth & $(-0.22)$ \\
\hline No NR dummy $*$ & -14.00 \\
gdp growth & $(-1.46)$ \\
\hline dln (real rice & $7.51 * * *$ \\
price) & $(7.46)$ \\
\hline dln (real maize & 0.442 \\
price) & $(0.51)$ \\
\hline n & 538 \\
\hline No. of countries & 39 \\
\hline Standard error & 3.93 \\
\hline
\end{tabular}

Notes. Country fixed effects included. Figures in parentheses are robust t-statistics. *, **, ***: significant at 10,5 and $1 \%$ respectively. Transformed inflation $=100 \mathrm{p} /(1+\mathrm{p})$, where $\mathrm{p}$ is the change in the log of consumer prices. The fiscal balance is the average of years T-3 to T. Output gap: deviation of $\ln$ (real GDP) from HodrickPrescott trend. 


\section{Determinants of fiscal balances}

Since fiscal balances were consistently significant in our inflation regressions, we end by considering some of the determinants of the fiscal balance. We regress the current-year fiscal balance as a percentage of GDP on a time trend, exchange rate regime dummies, political stability (or alternatively lagged real per capita GDP and a dummy for battle-related deaths), and dummies for richness in oil and other minerals. We also include the Chinn-Ito measure of capital account openness, in order to test whether capital account openness imposes fiscal discipline. The results are shown in Table 12, both with (columns 2 and 4) and without (columns 1 and 3) the lagged fiscal balance, which is highly significant, reflecting a strong element of persistence in the dependent variable.

The time trend has a positive coefficient, which is more significant for the larger sample, and which suggests a trend improvement in the fiscal balance of the average country by about $0.1 \%$ of GDP per year. The dummy for a hard peg exchange rate regime is significant at $5 \%$ or nearly so in all four cases, with a positive coefficient of about $2 \%$ of GDP. This could perhaps be interpreted as a reflection of the constraint on seigniorage revenue imposed by the hard peg. The dummy for floating always has a positive coefficient, but it never reaches the $5 \%$ level of significance. The capital account openness measure is significantly positive in the first column (the smaller sample without the lagged fiscal balance), but is never at all significant in the other three regressions. Political stability is statistically significant, with the expected positive coefficient. In the larger sample the battle-related deaths dummy always has a significant negative coefficient, which once again indicates that politically unstable countries tend to have worse fiscal balances. Countries rich in natural resources (especially but not exclusively oil) have significantly better fiscal balances than resource-poor economies, by over 5\% of GDP in the case of oil and by about $2 \%$ of GDP for other minerals. This presumably reflects natural resource rents, but also suggests that they are by no means all dissipated in higher expenditures. 
Table 12. Determinants of the fiscal balance/GDP

\begin{tabular}{|c|c|c|c|c|}
\hline $\begin{array}{l}\text { Dependent } \\
\text { variable: }\end{array}$ & $\begin{array}{c}\text { Fiscal } \\
\text { balance/GDP } \\
(\%)\end{array}$ & $\begin{array}{c}\text { Fiscal } \\
\text { balance/GDP } \\
(\%)\end{array}$ & $\begin{array}{c}\text { Fiscal } \\
\text { balance/GDP } \\
(\%)\end{array}$ & $\begin{array}{c}\text { Fiscal } \\
\text { balance/GDP } \\
(\%)\end{array}$ \\
\hline Constant & $\begin{array}{c}-9.36 * * * \\
(-5.61)\end{array}$ & $\begin{array}{c}-6.48 * * * \\
(-4.05)\end{array}$ & $\begin{array}{c}-8.59 * * * \\
(-4.87)\end{array}$ & $\begin{array}{l}-2.99 * * \\
(-2.16)\end{array}$ \\
\hline $\begin{array}{l}\text { Lagged fiscal } \\
\text { balance/GDP }\end{array}$ & & $\begin{array}{c}0.302 * * * \\
(4.14)\end{array}$ & & $\begin{array}{l}0.531 * * * \\
(7.72)\end{array}$ \\
\hline Time & $\begin{array}{l}0.0637 \\
(1.48)\end{array}$ & $\begin{array}{l}0.0438 \\
(1.14)\end{array}$ & $\begin{array}{c}0.107 * * * \\
(2.28)\end{array}$ & $\begin{array}{l}0.0418 \\
(1.14)\end{array}$ \\
\hline $\begin{array}{l}\text { Hard peg } \\
\text { dummy }\end{array}$ & $\begin{array}{l}2.55 * * * \\
(3.54)\end{array}$ & $\begin{array}{l}1.81 * * \\
(2.53)\end{array}$ & $\begin{array}{l}2.13 * * * \\
(3.31)\end{array}$ & $\begin{array}{l}1.02^{*} \\
(1.94)\end{array}$ \\
\hline Float dummy & $\begin{array}{l}0.438 \\
(0.80)\end{array}$ & $\begin{array}{l}0.444 \\
(0.89)\end{array}$ & $\begin{array}{l}0.811 \\
(1.38)\end{array}$ & $\begin{array}{l}0.500 \\
(1.10)\end{array}$ \\
\hline $\begin{array}{l}\text { Capital account } \\
\text { openness }\end{array}$ & $\begin{array}{c}0.392 * * * \\
(2.19)\end{array}$ & $\begin{array}{l}0.176 \\
(1.00)\end{array}$ & $\begin{array}{l}0.053 \\
(0.30)\end{array}$ & $\begin{array}{l}-0.008 \\
(-0.05)\end{array}$ \\
\hline $\begin{array}{l}\text { Political } \\
\text { stability }\end{array}$ & $\begin{array}{c}0.0878 * * * \\
(3.52)\end{array}$ & $\begin{array}{c}0.0577 * * \\
(2.45)\end{array}$ & & \\
\hline $\begin{array}{c}\text { Lagged } \\
\ln (\text { GDPpc in } \\
\text { constant US } \$)\end{array}$ & & & $\begin{array}{c}0.663 * * * \\
(2.62)\end{array}$ & $\begin{array}{l}0.165 \\
(0.78)\end{array}$ \\
\hline $\begin{array}{l}\text { Non-oil mineral } \\
\text { producer }\end{array}$ & $\begin{array}{c}1.83 * * * \\
(2.95)\end{array}$ & $\begin{array}{l}1.28 * * \\
(2.02)\end{array}$ & $\begin{array}{c}1.96 * * * \\
(3.23)\end{array}$ & $\begin{array}{c}0.91 \\
(1.52)\end{array}$ \\
\hline Oil producer & $\begin{array}{c}7.23 * * * \\
(8.65)\end{array}$ & $\begin{array}{l}5.01 * * * \\
(5.52)\end{array}$ & $\begin{array}{l}5.47 * * * \\
(7.01)\end{array}$ & $\begin{array}{c}2.86^{* * * *} \\
(3.80)\end{array}$ \\
\hline $\begin{array}{l}\text { Battle-related } \\
\text { deaths dummy }\end{array}$ & & & $\begin{array}{l}-1.62 * * \\
(-2.57)\end{array}$ & $\begin{array}{l}-1.46^{* *} \\
(-2.60)\end{array}$ \\
\hline $\mathrm{N}$ & 454 & 438 & 660 & 642 \\
\hline R-squared & 0.180 & 0.258 & 0.161 & 0.401 \\
\hline Standard error & 5.19 & 4.99 & 6.26 & 5.34 \\
\hline
\end{tabular}

Notes. Figures in parentheses are robust t-statistics. *, **, ***: significant at 10,5 and 1\% respectively.

Sample: SSA countries from 1996 onwards. Exchange rate regime data are from Bleaney and Tian (2014). 


\section{Conclusions}

Inflation has been somewhat higher in sub-Saharan Africa in recent years than in Latin America or in the Middle East and North Africa. Nevertheless inflation performance in subSaharan Africa has been better since 1995 than in the two decades up to that date. This is true whether we look at the median inflation rate across countries or at the proportion of countries with inflation above a threshold level of $10 \%$ or $20 \%$. The inflation rate was particularly high in 1994, and to a lesser extent 1995 also, because of the very large devaluation of the CFA franc in January 1994. To avoid the results being unduly influenced by this episode, our regression analysis is based on the period from 1996 onwards.

Fiscal deficits are correlated with inflation in SSA, although by themselves they explain very little of the variation in inflation across space and time. The fiscal deficit cumulated over several years shows a stronger correlation with inflation than the current year's deficit, which is consistent with the possibility of postponing the potentially inflationary effects of deficits through borrowing.

The multivariate regression analysis shows that inflation is higher in countries with higher political instability, with larger fiscal deficits and without a hard-peg exchange rate regime. Inflation targeting is not associated with lower inflation, but in sub-Saharan Africa that conclusion is based on the experience of only two countries. Inflation is highly persistent, but the same factors are statistically significant when this persistence is allowed for. Supplyside shocks are significant. Rising oil and rice prices, and falling output (presumably particularly in the agricultural sector, implying rising food prices) are associated with higher inflation rates.

Fiscal balances have been improving over time by about $0.1 \%$ of GDP per year on average. They are stronger in politically stable countries, in those that are resource-rich, and in those with a hard peg exchange rate regime.

The improvement in inflation and fiscal performance appears to reflect a general trend towards sounder monetary and fiscal policies, without significantly more widespread resort to commitment devices such as hard pegs or inflation targeting. This demonstrates that better macroeconomic policy can be achieved in a variety of ways, although they all involve a more 
mature and responsible approach to policy-making, with better communication and more willingness to stick to promises, even at the cost of some hard choices. Resolving conflict and achieving political stability is a significant component of this. Given the structure of African economies, supply-side shocks to prices are inevitable, but with appropriate policies they should be temporary.

\section{Acknowledgements}

The authors wish to thank an anonymous referee and participants in the World Bank project on Africa's Macroeconomic Vulnerabilities for helpful comments on a previous version.

\section{References}

Abidoye, B.O. and A.F. Odusola (2015) Climate change and economic growth in Africa: an econometric analysis, Journal of African Economies 24, 277-301

Barrios, S., L. Bertinelli and E. Strobl (2010) Trends in rainfall and economic growth in Africa: a neglected cause of the African growth tragedy, Review of Economics and Statistics $92,350-66$

Bleaney, M.F. and M. Francisco (2005) Exchange rate regimes and inflation - only hard pegs make a difference, Canadian Journal of Economics 38, 1453-71

Bleaney, M.F. and M. Tian (2014) Classifying exchange rate regimes by regression methods, University of Nottingham School of Economics Discussion Paper no. 14/02

Block, S.A. (2014) The post-independence decline and rise of crop productivity in subSaharan Africa: measurement and explanations, Oxford Economic Papers 66, 373-96

Catão, L.A.V. and M.E. Terrones (2005) Fiscal deficits and inflation, Journal of Monetary Economics 52, 529-554

Frankel, J. and S.-J. Wei (2008) Estimation of de facto exchange rate regimes: synthesis of the techniques for inferring flexibility and basket weights, IMF Staff Papers 55, 384-416

Gueye, C.A. and A.N.R. Sy (2015) Beyond aid: how much should African countries pay to borrow? Journal of African Economies 24, 352-366

Lin, H.-Y. and H.P. Chu (2013) Are fiscal deficits inflationary? Journal of International Money and Finance 32, 214-233

Male, R. (2010) Developing country business cycles: revisiting the stylised facts, Queen Mary University of London School of Economics and Finance working paper no. 664 
Reinhart, C.M. and K.S. Rogoff (2004) The modern history of exchange rate arrangements: a reinterpretation, Quarterly Journal of Economics 119, 1-48

Shambaugh, J.C. (2004) The effect of fixed exchange rates on monetary policy, Quarterly Journal of Economics 119, 301-352 